\title{
Ozone slows down anthracnose and increases shelf life of papaya fruits
}

\author{
Osvaldo Pereira da Silva Neto ${ }^{1}$, Elaine Vasconcelos da Silva Pinto², Márcio Akio Ootani ${ }^{3}$, \\ Joel Lima da Silva Junior ${ }^{4}$, Jânia Lilia da Silva Bentes Lima ${ }^{5}$, Aline Ellen Duarte de Sousa ${ }^{6}$
}

Financial disclousure

This work was developed and published with the support of the Government of the State of Amazonas through the Amazonas State Research Support Foundation - PAPAC/ FAPEAM)

Corresponding author: aedsousa@gmail.com

Received: February 18, 2019 Accepted: August 09, 2019

Copyright: All the contents of this journal, except where otherwise noted, is licensed under a Creative Commons Attribution License.

\begin{abstract}
This study investigated the effect of ozone on papaya postharvest conservation, aiming at controlling anthracnose and increasing fruit shelf life. The experiment was conducted at the Laboratory of Product Technology, Federal University of Amazonas, Manaus-AM. Fruits were treated with $0 ; 0.6 ; 1.5$ and $3.3 \mathrm{ppm}$ ozone and commercial fungicide. They were then stored at room temperature $\left(27 \pm 2{ }^{\circ} \mathrm{C}\right.$ and $\left.65 \pm 5 \% \mathrm{RH}\right)$. Incidence, severity, number and size of anthracnose lesions were determined, as well as postharvest quality by assessing shelf life; accumulated and daily fresh mass loss (\%), peel color, electrolyte leakage (\%), soluble solids (\%), titratable acidity $\left(\mathrm{g} 100 \mathrm{~g}^{-1}\right)$, soluble solids / titratable acidity ratio, $\mathrm{pH}$ and vitamin $\mathrm{C}\left(\mathrm{mg} 100 \mathrm{~g}^{-1}\right)$. Ozone reduced anthracnose severity in the short (3.3 ppm) and long term (1.5 ppm), making it as effective as a commercial fungicide. Ozone increased shelf life by seven days and maintained the postharvest quality of papaya fruits. Thus, ozone becomes a potential technology for postharvest use as a safe alternative to the use of pesticides in reducing anthracnose and increasing shelf life of papaya fruits. Index terms: Carica papaya L., alternative treatment, anthracnose, postharvest.
\end{abstract}

\section{Ozônio retarda a antracnose e aumenta a vida útil de mamão}

Resumo - O estudo investigou o efeito do ozônio na conservação pós-colheita de mamão, visando ao controle da antracnose e ao aumento da vida útil dos frutos. O experimento foi realizado no Laboratório de Tecnologia de Produto, da Universidade Federal do Amazonas, Manaus-AM. Os frutos foram tratados com 0; 0,6; 1,5 e 3,3 ppm de ozônio e fungicida comercial. Em seguida, foram conservados em temperatura ambiente $\left(27 \pm 2{ }^{\circ} \mathrm{C}\right.$ e $65 \pm 5 \%$ UR). Determinou-se a incidência, a severidade, o número e o tamanho das lesões da antracnose; e a qualidade pós-colheita, por meio da avaliação da vida útil; a perda de massa fresca acumulada e diária (\%), a cor da casca, o extravasamento de eletrólitos (\%), os sólidos solúveis (\%), a acidez titulável ( $\left.100 \mathrm{~g}^{-1}\right)$, a relação $\mathrm{SS} / \mathrm{AT}$, pH e vitamina C (mg $100 \mathrm{~g}-1)$. O ozônio reduziu a severidade da antracnose a curto (3,3 ppm) e a longo prazos (1,5 ppm), tornando-se efetivo tanto quanto o fungicida comercial. O ozônio aumentou em sete dias a vida útil e manteve a qualidade pós-colheita dos frutos de mamão. Assim, o ozônio torna-se uma tecnologia potencial para uso em pós-colheita, como alternativa segura ao uso de agrotóxicos na redução da antracnose e no aumento da conservação dos frutos de mamão. Termos para indexação: Carica papaya L., tratamento alternativo, antracnose, pós-colheita. 


\section{Introduction}

Papaya (Carica papaya L.) is one of the most important tropical and subtropical fruits currently grown in the world (AKTARUZZAMAN et al., 2018). In the global scenario, Brazil occupies a prominent position with production of approximately 1.06 million tons in 2017 (IBGE, 2019). Its cultivation occurs in almost all national territory and the states of Bahia, Espírito Santo and Ceará are responsible for $75 \%$ of production (IBGE, 2019), which makes Brazil among the largest exporters, with the European market as its main destination.

However, significant part of papaya fruits produced are discarded mainly due to their high perishability, which is related to their climatic metabolism, that is, they present postharvest respiratory elevation and ethylene production peaks. However, high ethylene production rates anticipate ripening and consequent senescence, reducing fruit shelf life. Moreover, it is at this development stage that symptoms of many postharvest fruit diseases are observed.

Anthracnose in papaya, which has Colletotrichum gloeosporioides (Penz.) as its causative agent, is considered to be the main postharvest disease that causes losses due to microbiological deterioration in papaya (Carica papaya L.) fruits, which limits the export of this fruit by producers in Brazil and other countries (LIBERATO; TATAGIBA, 2001).

Methods for removing or decreasing the severity of fruit rot-causing microorganisms (phytopathogens) have been based on pesticide applications. Papayas are generally treated with fungicides such as imazalil (Imidazole, MAPA register No. 3498) and thiabendazole (Benzimidazole, MAPA register No. 09001). However, the persistent use of these fungicides results in the emergence of resistant strains (JINASENA et al., 2011). In addition, there is concern about risks to human health caused by pesticide residues in fruits (SUÁREZQUIROZ et al., 2013).

Therefore, to obtain good quality fresh vegetables and export standards, postharvest management techniques and methods for papaya fruits have been used in order to ensure quality and extend the shelf life of fruits. Among the methods that have been used to control postharvest diseases, ozone, the triatomic form of oxygen $\left(\mathrm{O}_{3}\right)$ has been promising because it is a strong oxidant and has short half-life (ONG et al., 2013).

Ozone treatments at concentrations ranging from 0.15 to $5 \mathrm{mg} \mathrm{L}^{-1}$ have inhibited the growth of phytopathogenic microorganisms in lettuce (TRINETTA et al., 2011), asparagus (QIANG et al., 2005), carrot (SHARPE et al., 2009), orange (PATIL et al., 2009), apple (SHARPE et al., 2009), papaya (ONG and ALI, 2015), melon (TRINETTA et al., 2011); strawberry (ADAY and CANER, 2014) and tangerine (BOONKORN et al., 2012).

The effectiveness of ozone treatments in inhibiting mycelial growth and spore production of rot-causing microorganisms in fruits and vegetables is directly related to ozone concentration and time of exposure (TZORTZAKIS et al., 2007; NGO et al., 2013). According to Ozkan et al. (2011) the best inhibition results occur at higher ozone concentrations.

Another advantage attributed to the use of ozone is the increased conservation and maintenance of postharvest quality, especially in climacteric fruits, because it oxidizes ethylene released by fruits (SKOG and CHU, 2001). There are few studies relating this gas to postharvest conservation and quality (ZAMBRE et al., 2010; ALEXANDRE et al., 2012; KECHINSKI et al., 2012), being restricted to its effect on disease control. However, there are studies that have shown that ozone does not influence fruit quality parameters, such as color, sugar content, acidity, $\mathrm{pH}$ and weight loss (KLOCKOW; KEENER, 2009; RODONI et al., 2009; VENTA et al., 2010; MINAS et al., 2012). Thus, the use of ozone may be a potent method alternative to the use of synthetic products in disease control, without leaving toxic residues and without affecting the quality of fruits and vegetables.

Given the above, it was hypothesized that ozone reduces anthracnose in papaya, increasing its shelf life, without affecting the postharvest quality of fruits. Thus, the aim of this study was to evaluate the effect of ozone on postharvest conservation of papaya fruits.

\section{Material and Methods}

Plant material and application of treatments - Papaya (Carica papaya L.) fruits 'Sunrise Solo' cultivar at maturity stage 1 were used (fruit with up to $15 \%$ yellow peel), purchased at the local producers' fair of the municipality of Manaus-AM. Fruits were transported to the Laboratory of Product Technology (LTP) of the Federal University of Amazonas (UFAM), standardized for color and absence of defects, washed with neutral detergent $(0.2 \%)$ and air dried for 1 hour; then submitted to treatments. Ozone application occurred in hermetically sealed boxes (1000 L), coupled to an ozone generator (model TES 125, Interozone, Brazil) with concentration regulation. Fruits were exposed to different ozone concentrations for $4 \mathrm{~h}$. Commercial fungicide (Nativo ${ }^{\circledR}, 1.2 \mathrm{ml} \mathrm{L}^{-1}$ ) was manually applied with the aid of a spray bottle $(1 \mathrm{~L})$. Treatments were divided into: 0 (control); $0.6 ; 1.5$ and 3.3 ppm ozone 
and fungicide. After application of treatments, fruits were placed on benches, kept at room temperature (27 $\pm 2{ }^{\circ} \mathrm{C}$ and $\left.65 \pm 2 \% \mathrm{RH}\right)$, and submitted to evaluations.

Phytosanitary action of ozone - Anthracnose incidence was determined by the average amount of infected fruits, detected based on disease symptomatology (ASSUNÇÃO et al., 2018), and results were expressed as \%. Disease severity was determined based on the area injured by anthracnose, according to methodology proposed by Azevedo (1997), and results were expressed as $\%$. The average number of injuries was determined by the injury count. The size of lesions was measured with the aid of a graduated ruler, and results were expressed as $\mathrm{mm}^{2}$ (RIBEIRO et al., 2016).

\section{Postharvest quality of ozone-treated fruits -}

Shelf life was estimated by assessing external appearance of fruits on a daily basis, following a decreasing scale of scores ranging from 5 to 0 , according to Sousa et al. (2019). Upon reaching score 2, fruits were discarded as they were considered unsuitable for commercialization (end of shelf life). Fruit mass loss was daily determined until the end of shelf life. Subsequently, accumulated mass loss (AML) was calculated according to the following formula $\mathrm{AML}=($ Initial Weight $/$ Final Weight $)$ * 100. Daily mass loss (DML) was determined by the AML / number of days of each treatment ratio. AML and DML were expressed as \%. Peel color was assigned through scores 1 to 5 according to yellowing, established as the basis for ripening stages of the Brazilian papaya classification $(\mathrm{CQH}, 2003)$. Leakage was determined according to Sousa et al. (2017), with modifications. Cylinders $\left(1.0 \mathrm{~cm}^{2}\right)$ removed from the peel region were incubated in vials containing $20 \mathrm{~mL}$ distilled water, and allowed to stand for $6 \mathrm{~h}$. After rest, the initial solution electrical conductivity (CEi) was measured with the aid of a conductivity meter (Digimed, Model DM 3P). Then, samples were placed in an oven at $90{ }^{\circ} \mathrm{C}$ for $2 \mathrm{~h}$. After this period, vials were left on the bench until solution was equilibrated to room temperature $\left(27 \pm 1{ }^{\circ} \mathrm{C}\right)$. Electrical conductivity was measured again, expressing the total electrolyte leakage (ECf). Electrolyte leakage (EL) was calculated using the following formula $\mathrm{EL}=(\mathrm{CEi}) / \mathrm{CEf}) * 100$, and results were expressed as $\%$ of total conductivity. Soluble solids content (SS) of pulp was performed with the aid of a digital refractometer (Instrutherm Brazil ${ }^{\circledR}$, RTDS-28) with automatic temperature compensation. Results were expressed as \% (AOAC, 2005). Titratable acidity (TA) was determined by titration with previously standardized $0.1 \mathrm{~N} \mathrm{NaOH}$ until light pink coloration. The solution was composed of $1 \mathrm{~g}$ of pulp, $50 \mathrm{~mL}$ of distilled water and 2 drops of $1 \%$ alcohol phenolphthalein. Results were expressed as \% citric acid (AOAC, 2005). The SS / TA ratio was determined by the ratio between soluble solids content and titratable acidity. $\mathrm{pH}$ was measured directly in the pulp with the aid of a digital potentiometer with automatic temperature adjustment, duly standardized with $\mathrm{pH} 7.0$ and 4.0 buffer solutions (AOAC, 2005). Vitamin C was obtained by titration with DCPI solution (2,6-dichlorophenolindophenol, $0.02 \%$ ) until permanent light pink color using 1 gram of pulp diluted in $100 \mathrm{~mL}$ of oxalic acid $(0.5 \%)$ (SOUSA et al., 2017). Results were expressed as mg of ascorbic acid $100 \mathrm{~g}^{-1}$ pulp.

Experimental design and statistical analysis For phytosanitary evaluations, a completely randomized design (CRD) with 10 replicates was used, and evaluations were daily performed until fruit disposal (end of shelf life). Data collected were submitted to regression analysis considering storage time and analysis of variance. Means were compared by the Tukey test at $5 \%$ probability. CRD with 10 repetitions was used for the analysis of shelf life, AML and DML, and evaluations were daily performed until fruit disposal; and 5 replicates for the other postharvest evaluations, with evaluations performed at the beginning and end of the fruit shelf life. Data collected were submitted to analysis of variance and means compared by the Tukey test at $5 \%$ probability. To determine shelf life, survival analysis was performed using the Kaplan-Meier test by LogRank, using the free R software. Pearson's correlation coefficient was estimated for all variables at 1 and $5 \%$ significance level by the Student's t-test.

\section{Results and Discussion}

For the plant health test, incidence, severity, number and size of lesions were evaluated. All regressions were significant, with equations showing quadratic behavior for all treatments tested on all variables (Table 1). The determination coefficient $\left(\mathrm{R}^{2}\right)$ followed the trend line, ranging from 0.90 to 0.96 for incidence; 0.91 to 0.97 for severity; 0.87 to 0.97 for number of lesions and 0.88 to 0.99 for lesion size. The accuracy of disease assessment will be greater the closer $\mathrm{R}^{2}$ is to 1 .

The evaluation period for the regression analysis was until the sixth day, which corresponds to the end of the shelf life of fruits that were not exposed to ozone (control) (Figure 2). According Pimentel et al. (2011), this is the average storage time of papaya at room temperature (approximately $25^{\circ} \mathrm{C}$ ). The first fruits to present anthracnose symptoms were those from the control group and those exposed to $1.5 \mathrm{ppm}$ ozone on the third day of conservation (Figure 1A).

The anthracnose incidence increased with the conservation period, with $100 \%$ incidence on the sixth day for control, ninth day for fruits exposed to $1.5 \mathrm{ppm}$ ozone, twelfth day for fruits exposed to 0.6 and 3.3 
ppm ozone and fourteenth day for fruits treated with fungicide. These results allowed inferring that ozone delayed pathogen infection because on the sixth day, the incidence of anthracnose in fruits exposed to ozone was below $30 \%$. Ong et al. (2013) also found that ozone delayed the onset of anthracnose in papaya fruits.

Anthracnose severity increased over the conservation period (Figure 1B). On the sixth day, severity of 24.2 can be observed; $8 ; 6.5 ; 3.7$ and $1.3 \%$ for control fruits, $1.5 \mathrm{ppm}, 0.6 \mathrm{ppm}$, fungicide and 3.3 ppm ozone, respectively, was observed. The number and size of anthracnose lesions also increased over the conservation period (Figures 1C and D).

On the sixth day, fruits exposed to the highest ozone concentration (3.3 ppm) presented lower average number of lesions and lesion size, which corresponds to reduction of $91.8 \%$ and $84.7 \%$, respectively. This explains the lower disease severity in these fruits, indicating greater effectiveness of ozone at concentration of $3.3 \mathrm{ppm}$ in reducing anthracnose symptoms in the short term.

Table 2 shows the mean severity values, number and size of lesions in fruits treated with ozone and fungicide at the beginning and end of the conservation period. It was possible to observe the effect of treatments only for severity and size of lesions.

The mean severity, number and size of lesions of all treatments in relation to control were similar (Table 2); however, it should be taken into account the delay in days of fruits exposed to ozone to reach the same severity, number and size of anthracnose lesions, which was six days for fruits treated with $3.3 \mathrm{ppm}$ ozone and seven days for fruits treated with 0.6 and $1.5 \mathrm{ppm}$ ozone. Thus, it was found that ozone had fungistatic effect in the short term.

This fungistatic effect possibly occurred due to ozone reacting with water and initiating the formation of oxidizing species, which result in damage to the cell membranes of microorganisms, altering their permeability and affecting cell integrity. In addition, ozone as a biocidal agent may have multiple targets, such as proteins, enzymes and even DNA (KIM; YOUSEF, 2000; THANOMSUB et al., 2002). Ong and Ali (2015) suggest mitochondrial degradation of $C$. gloeosporioides spores as the main mode of ozone effect on anthracnose in papaya. In addition, ozone may induce physiological responses in fruits that lead to the synthesis of secondary metabolites involved in plant defense to pathogen such as phenolic compounds, antioxidants and others (ALOTHMAN et al., 2010; MODESTI et al., 2018), and this may induced greater resistance of fruits to the disease development.
The effect of storage time on severity, number and size of lesions was verified. The averages of these variables ranged from 0 at the beginning of the conservation period to $27.7 \%, 3.84$ and $1914 \mathrm{~mm}^{2}$ (severity, number and size of lesions, respectively) at the end of the conservation period (Table 2). Colletotrichum species cause latent infections, that is, infection without the appearance of symptoms in fruits of various hosts, which penetrate the green fruit and remain inactive until ripening (AMORIM; PASCHOLATI, 2018). It is possible that this phytopathogen behavior has occurred, with the manifestation of symptoms over the conservation period and fruit ripening. Through survival analysis, it was possible to observe that the ozone doses applied increased the shelf life of papaya fruits (Figure 2). The average shelf life in which 50\% of fruits developed senescence symptoms was four days for fruits not exposed to ozone (control), seven days for fruits treated with $0.6 ; 1.5$ and 3.3 ppm ozone and nine days for fruits treated with commercial fungicide.

End of shelf life occurred when $100 \%$ of fruits were discarded because they were considered unsuitable for commercialization, that is, when all fruits were affected by depressions or spots of medium intensity. Thus, the end of shelf life was six days for control, twelve days for fruits exposed to $3.3 \mathrm{ppm}$ ozone, thirteen days for fruits exposed to 0.6 and $1.5 \mathrm{ppm}$ ozone and fourteen days for fruits treated with commercial fungicide. Thus, the lowest ozone concentrations used in this work ( 0.6 and $1.5 \mathrm{ppm})$ increased the shelf life of papaya fruits stored at room temperature by seven days. The effect of ozone is dependent on concentration used and type of fruit (MILLER et al., 2013). In the case of papaya, concentration of 3 ppm may have induced oxidative stress, which impaired external appearance and consequently reduced fruit shelf life.

Influence of treatments and storage time for AML and DML of papaya fruits was observed (Table 3). Control fruits had lower AML, which can be explained by the lower exposure of fruits to the environment, due to their shorter shelf life, which was six days (Figure 2). In contrast, when evaluating DML, fruits exposed to ozone and those treated with fungicide presented the lowest daily mass loss. Lower fresh mass loss values were also observed for strawberries (KEUTGEN and PAWELZIK, 2008) and blueberries (KIM et al., 2003) stored in ozone enriched atmosphere. In contrast, weight loss was higher (ALI et al., 2014; CONTIGIANI et al., 2018) or did not change (PALOU et al., 2002) in table grapes stored in ozone-enriched environment compared to control. Some authors suggest that ozone alters the disposition of cuticle and / or epidermal tissues, which may favor or hinder fresh mass loss (CONTIGIANI et al., 2018). It has been suggested that higher ozone 
levels or prolonged ozone exposure may result in cuticle damage (PALOU et al., 2002; CONTIGIANI et al., 2018), and the severity of the damage varies by species and development stage of fruits.

AML and DML at the end of conservation were $13.9 \mathrm{~g}$ and $1.26 \mathrm{~g}$, respectively (Table 3 ).

Fruit peel color changed as a function of shelf life (Table 3). Costa (2012) obtained similar result, in which ozone also did not change the color of papaya fruits. However, effect of time on color change was observed, with initial average score of 1 (up to $15 \%$ of yellowish peel) evolving to 4.6 (50 to $70 \%$ of yellowish peel) at the end of the environment conservation period. The change in papaya fruit color, which is a visual indication of ripeness, occurs with chlorophyll degradation, initiating senescence, which is an irreversible process (BHANUSHREE et al., 2018).

Treatments did not change EL, SS, TA, SS / TA, $\mathrm{pH}$ and vitamin C. However, time effect was verified for SS, EL, TA and pH (Table 3).

EL increased by approximately $43 \%$, from 25.6 at the beginning to $59.5 \%$ at the end of the conservation period (Table 3). Increased EL during the storage time indicates loss of integrity (selective permeability) of the cell membrane system due to maturation (SOUSA et al., 2017). The mean SS value found in this study, $11.1 \%$ (Table 3), is in agreement with literature, with values ranging from 5 to 19\% (SOUZA et al., 2014; DA SILVA FREITAS et al., 2018). At the end of the storage period, the SS content was lower compared to the beginning, with reduction of $0.5 \%$ (Table 3 ).

Like SS, TA also decreased at the end of the storage period (Table 3 ), with values within literature found for papaya, which are generally less than $0.2 \%$ citric acid (SOUZA et al., 2014; BRON; JACOMINO, 2006). Overall, SS and TA decrease during the conservation period, probably due to their use in the respiration process (GOL et al., 2013; JOSHI et al., 2017). For the SS / TA ratio, the average value found was 69.4 (Table 3), which is within values found in literature for papaya fruits, with very variable values, from 32 to 250 (FONTES et al., 2012; SOUZA et al., 2014). This relationship indicates the balance between sugar and acid content of fruits and directly contributes to the formation of flavor and aroma. Fruits with higher SS / TA values generally have more pronounced sweetness and lower acidity, being preferred by consumers (VIANA et al., 2015). The $\mathrm{pH}$ values increased slightly over time, from 5.2 at the beginning to 5.3 at the end of the storage period (Table 3). This increase may be related to the reduction of acidity. According to Pimentel et al. (2011), pH variations are due to a more advanced maturation level. Vitamin $\mathrm{C}$ was not affected by ozone and did not vary during shelf life (Table 3). Costa (2012) also found that the exposure of papaya fruits to ozone did not change vitamin $C$ contents. The average vitamin $C$ value in

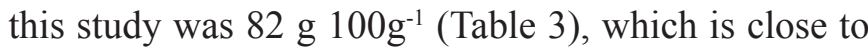
values obtained by other studies in literature (REIS et al., 2015a, b; IAMJUD et al., 2016). In studies of pineapple, banana, papaya and grapes exposed to ozone, vitamin C content decreased (ALOTHMAN et al., 2010; YEOH et al., 2014). Ascorbic acid is thermolabile and highly sensitive to various processing and storage conditions. Possibly, the ozone concentrations used in this work were not high enough to affect the vitamin $\mathrm{C}$ content of fruits.

Pearson's correlation analysis was performed to verify which variables most influenced fruit shelf life (Table 4). It was observed that only disease severity was significant, that is, the one that most negatively influenced (-0.36) fruit shelf life. This negative correlation indicates that the higher the disease severity, the shorter the shelf life, as observed in this study. The mean anthracnose severity value found in this study was not significant, with $27.7 \%$ at the end of the storage period (Table 2). This was due to other factors, such as mass loss, also influencing product depreciation, which led to fruit disposal even before anthracnose developed in at least 50\%. However, through Pearson correlation, the DML as well as the other variables did not significantly reduce fruit shelf life. 


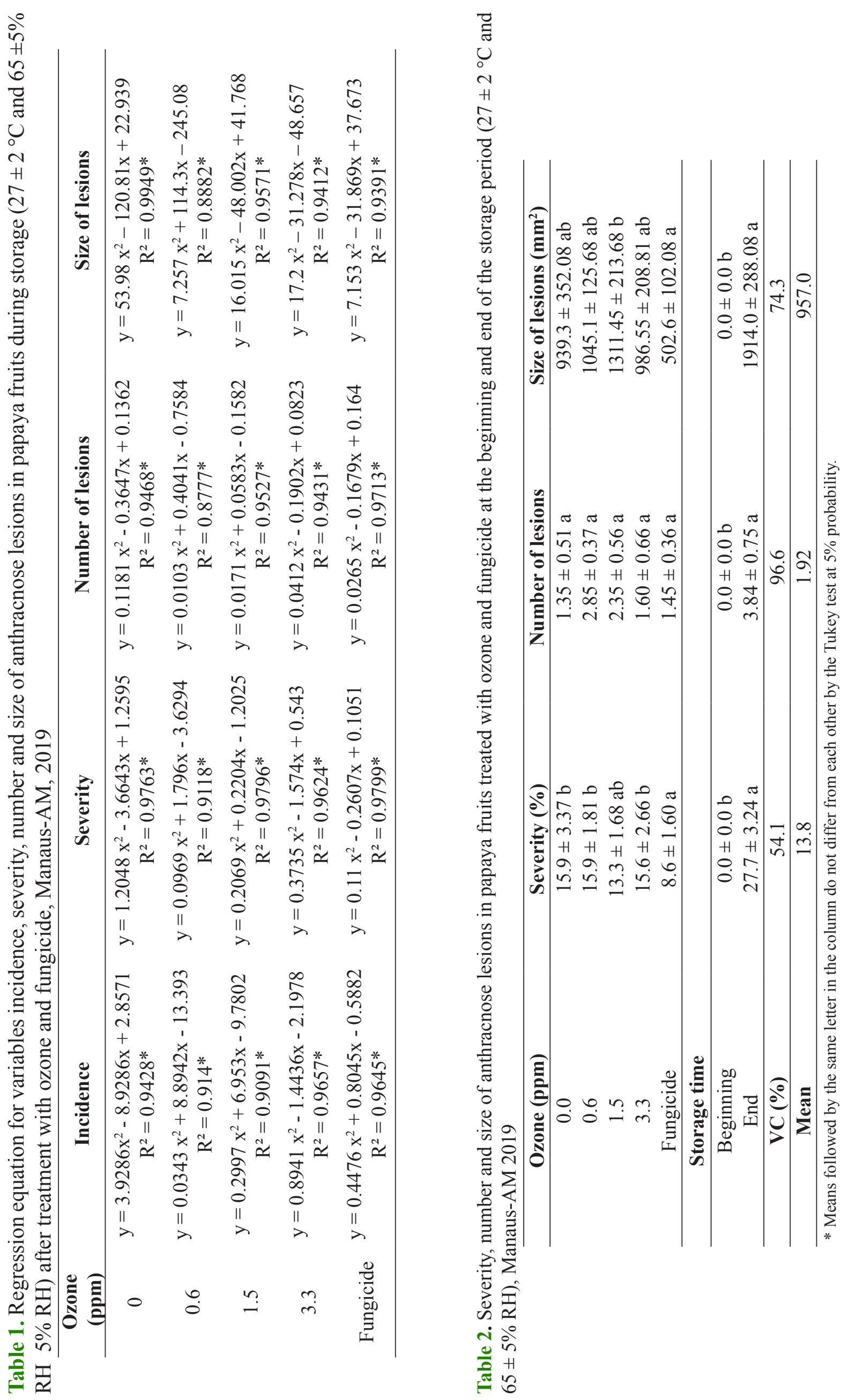




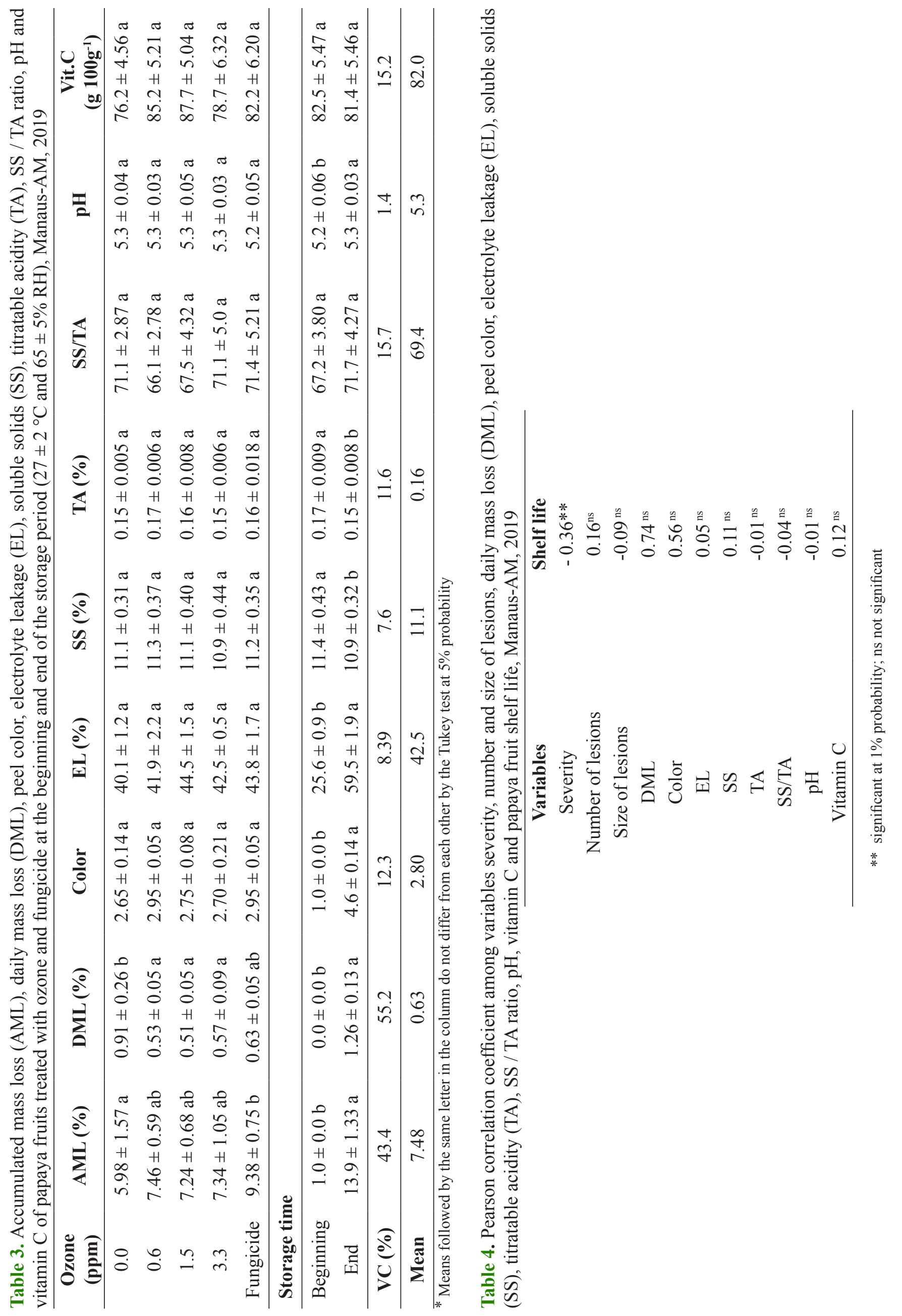



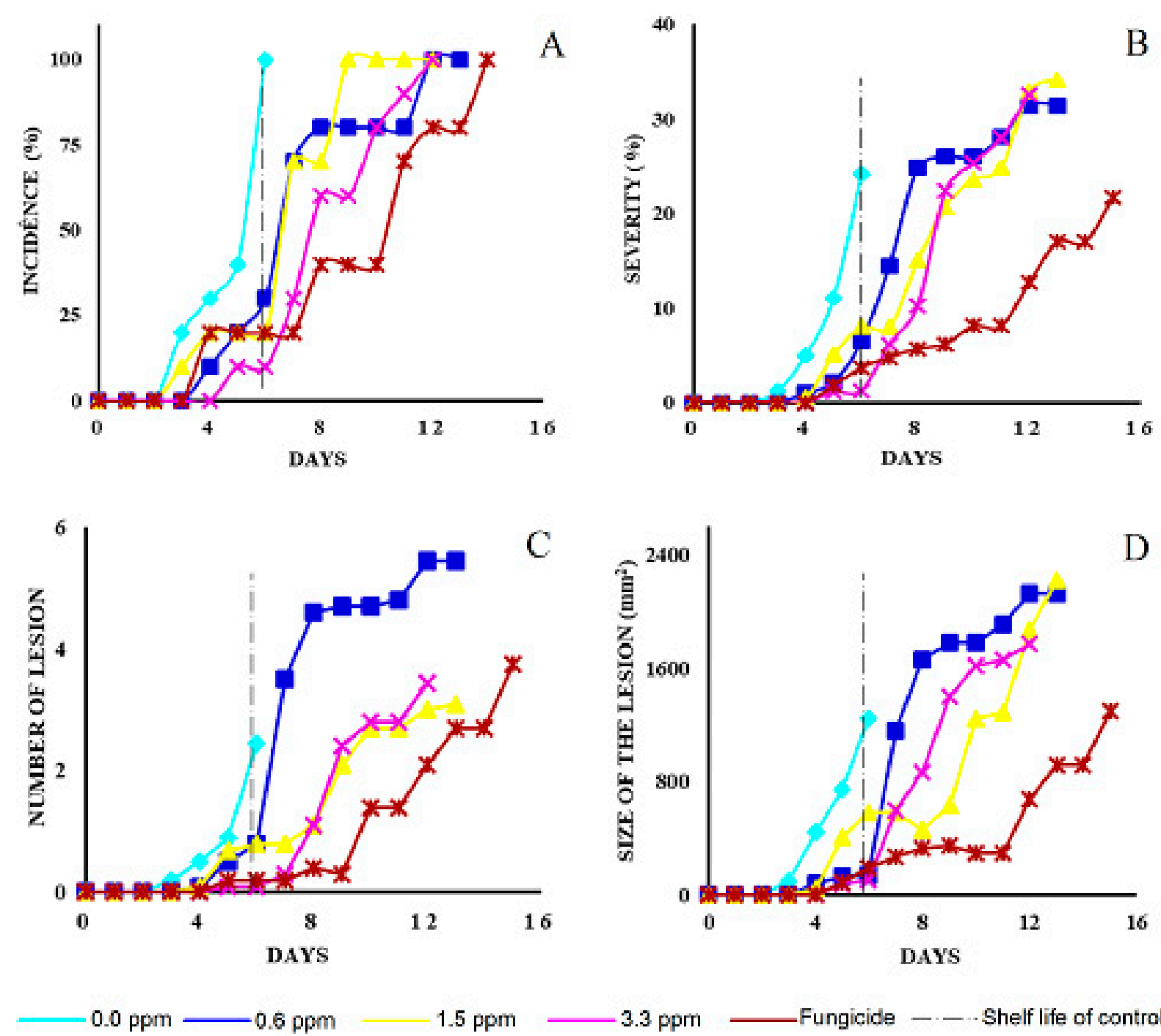

$3.3 \mathrm{ppm}$

_Fungicide

Shelf life of control

Figure 1. Incidence (A), severity (B), number (C) and size of lesions (D) caused by anthracnose in papaya fruits treated with ozone and fungicide during the storage period $\left(27 \pm 2{ }^{\circ} \mathrm{C}\right.$ and $\left.65{ }^{\circ} \mathrm{C} \pm 5 \% \mathrm{RH}\right)$, Manaus-AM, 2019 


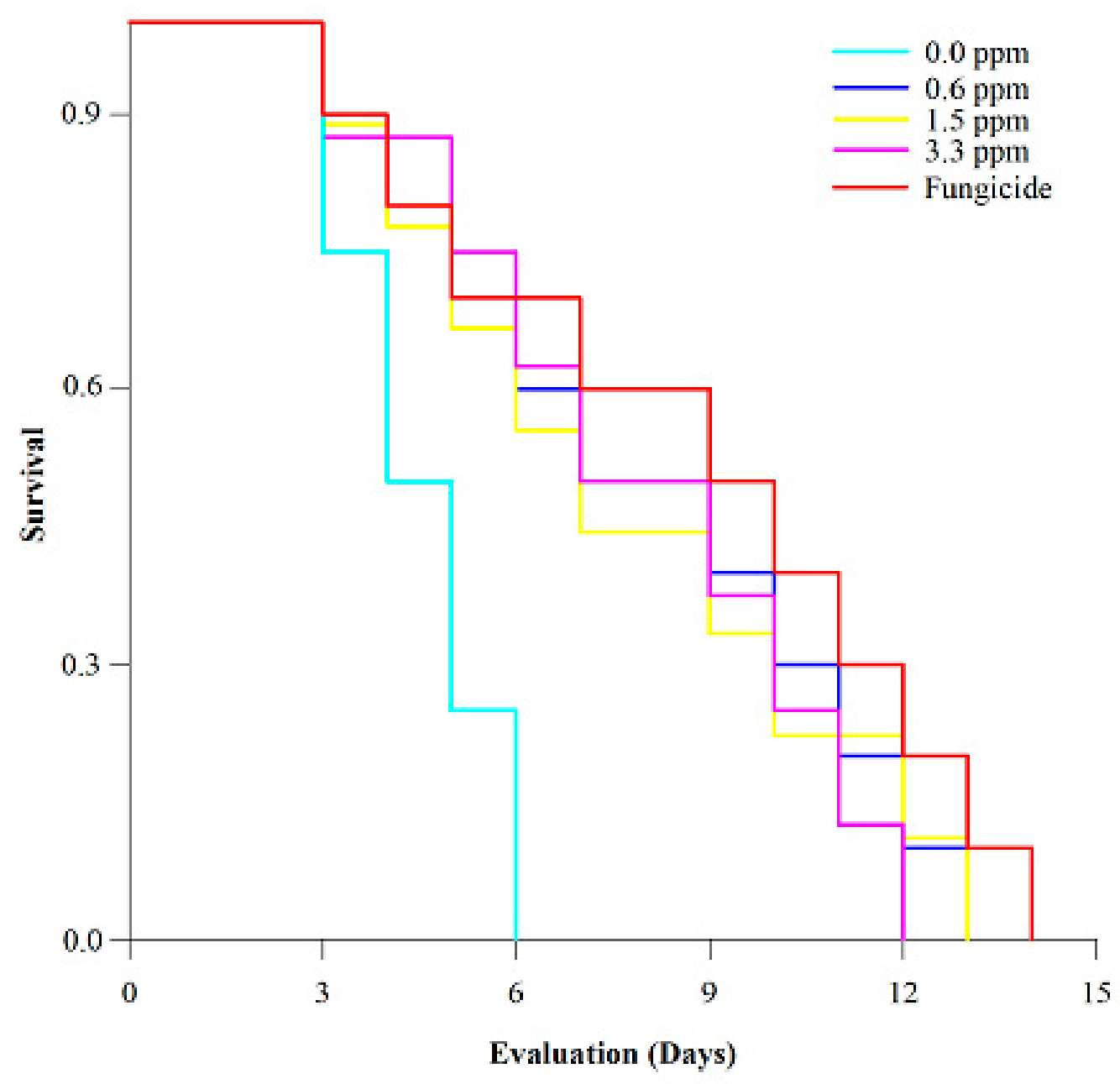

Figure 2. Shelf life of papaya fruits submitted to ozone and fungicide treatments $\left(27 \pm 2{ }^{\circ} \mathrm{C}\right.$ and $\left.85 \pm 5 \% \mathrm{RH}\right)$, Manaus-AM, 2019

\section{Conclusions}

Ozone was as effective as commercial fungicide in reducing anthracnose severity in the short term, showing fungistatic effect at concentration of $3.3 \mathrm{ppm}$ and in long-term at concentration of $1.5 \mathrm{ppm}$. The reduction of anthracnose severity using ozone was crucial to increase fruit shelf life by up to seven days. In addition, ozone maintained the quality of papaya fruits. Therefore, ozone becomes a potential technology for postharvest use as an alternative to the use of pesticides to reduce anthracnose in papaya fruits.

\section{References}

ADAY, M.S.; CANER, C. Individual and combined effects of ultrasound, ozone and chlorine dioxide on strawberry storage life. LWT-Food Science and Technology, Amsterdam, v.57, n.1, p.344-351, 2014.

AKTARUZZAMAN, M.D.; AFROZ, T.; KIM, B.S. Postharvest anthracnose of papaya caused by Colletotrichum truncatum in Korea. European Journal of Plant Pathology, Dordrecht, v.150, n.1, p.259-265, 2018.

ALEXANDRE, E.M.; BRANDÃO, T.R.; SILVA, C.L. Efficacy of non-thermal technologies and sanitizer solutions on microbial load reduction and quality retention of strawberries. Journal of Food Engineering, Amsterdam, v.108, n.3, p.417-426, 2012. 
ALI, A.; ONG, M.K.; FORNEY, C.F. Effect of ozone pre-conditioning on quality and antioxidant capacity of papaya fruit during ambient storage. Food Chemistry, London, v.142, p.19- 26, 2014.

ALOTHMAN, M.; KAUR, B.; FAZILAH, A.; BHAT, R.;KARIM, A. A. Ozone-induced changes of antioxidant capacity of fresh-cut tropical fruits. Innovative Food Science \& Emerging Technologies, New York, v.11, n.4, p.666-671, 2010.

AMORIM, L.; PASCHOLATI, S.F. Ciclo das relações patógeno-hospedeiro. In: AMORIM, L.; REZENDE, J.A.M.; BERGAMIM FILHO, A. Manual de fitopatologia. Princípios e conceitos. 5.ed. Ouro Fino: Ed. Agronômica Ceres, 2018. v.1, p.45-69.

ASSUNÇÃO, M.C., AMARAL, A.G.G.; LINS, F.J.A. Efeito da temperatura e de embalagens sobre a antracnose em frutos de manga cv. tommy atkins. Revista Ciência Agrícola, Maceió, v.16, n.3, p.35-42, 2018.

AOAC - Association of Official Analytical Chemistry. Official methods of analysis of the Association of Official Analytical Chemistry. $17^{\text {th }}$ ed. Washington, 2005. 1115 p.

AZEVEDO, L.A.S. Manual de quantificação de doenças de plantas. São Paulo, 1997. 114p.

BOONKORN, P.; GEMMA, H.; SUGAYA, S.; SETHA, S.; UTHAIBUTRA, J.; WHANGCHAI, K. Impact of high-dose, short periods of ozone exposure on green mold and antioxidant enzyme activity of tangerine fruit. Postharvest Biology and Technology, Amsterdam, v.67, p.25-28, 2012.

BHANUSHREE，L.S.; VASUDEVA，K.R.; SURESHA, G.J.; SADANANDA, G.K.; MOHAMAD TAYEEBULLA, H.; HALESH, G.K. Influence of chitosan on postharvest behavior of papaya (Carica papaya L.) Fruits under different storage conditions. Journal of Pharmacognosy and Phytochemistry, Haryana, v.7, n.2, p.2010-2014, 2018.

BRON, I.U; JACOMINO, A.P. Repening and quality of 'Golden' papaya fruit harvested of different maturity stages. Brazilian Journal Plant Physiology, Campinas, v.108, n.3, p.389-396, 2006.

$\mathrm{CQH}$ - Centro de Qualidade em Horticultura. Programa Brasileiro para a Modernização da Horticultura. Normas de classificação do mamão. São Paulo: $\mathrm{CQH} /$ CEAGESP, 2003. (Documentos, 25).
CONTIGIANI, E.V.; JARAMILLO-SÁNCHEZ, G., CASTRO, M.A., GÓMEZ, P.L.; ALZAMORA, S.M. Postharvest quality of strawberry fruit (Fragaria $x$ Ananassa Duch cv.Albion) as affected by ozone washing: fungal spoilage, mechanical properties, and structure. Food and Bioprocess Technology, New York, v.11, n.9, p.1639-1650, 2018.

COSTA, A.R. Ozônio como agente fungicida na pós-colheita do mamão (Carica papaya L.). 2012. Dissertação (Mestrado) - Universidade Federal de Viçosa, Viçosa, 2012.

DA SILVA FREITAS, R.V.; DE SOUZA, P.A.; SENHOR, R.F.; MOURA, C.F.H.; DA COSTA, F.B. Armazenamento pós-colheita de frutos do mamoeiro recobertos com extratos das folhas e frutos do nim. Revista Caatinga, Mossoró, v.31, n.2, p.290-296, 2018.

GOL, N.B; PATEL, P.R; RAO, T. R. Improvement of quality and shelf-life of strawberries with edible coatings enriched with chitosan. Postharvest Biology and Technology, Amsterdam, v.85, p.185-195, 2013.

FONTES, R.V.; VIANA, A.P.; PEREIRA, M.G.; OLIVEIRA, J.G.; VIEIRA, H.D. Manejo da cultura do híbrido de mamoeiro (Carica papaya L.) do grupo 'formosa' UENF/CALIMAN - 01 para melhoria na qualidade do fruto com menor aplicação de adubação NPK. Revista Brasileira de Fruticultura, Jaboticabal, v.34, n.1, p.143-151, 2012.

IAMJUD, K.; SRIMAT, S.; SANGWANANGKUL, P.; WASEE, S.; THAIPONG, K. Antioxidant properties and fruit quality of selected papaya breeding lines. Science Asia, Bangkok, v.42, p.332-339, 2016.

IBGE - Instituto Brasileiro de Geografia e Estatística. Produção agrícola municipal. Rio de Janeiro, 2016. Disponível em: https://sidra.ibge.gov.br/ tabela/5457\#resultado. Acesso em: 15 feb. 2019.

J I N A S ENA, D.; PAT H IR AT HNA, P.; WICKRAMARACHCHI, S.; MARASINHE, E. Use of chitosan to control anthracnose on "Embul" banana. In: INTERNATIONAL CONFERENCE ON ASIA AGRICULTURE AND ANIMAL, 13., 2011. Hong Kong. Proceedings [...]. Hong Kong: IPCBEE, 2011. p.56-60. 
JOSHI, A. V.; BARAIYA, N.S.; VYAS, P.B.; RAO, T. R. Gum ghatti based edible coating emulsion with an additive of clove oil improves the storage life and maintains the quality of papaya (Carica papaya L., cv. Madhu bindu). International Journal of Current Microbiology and Applied Sciences, Tamilnadu, v.6, n.5, p.160-174, 2017.

KECHINSKI, C.P.; MONTERO, C.R.S.; GUIMARÃES, P.V.R.; NOREÑA, C.P.Z.; MARCZAK, L.D.F.; TESSARO, I.C.; BENDER, R.J. Effects of ozonized water and heat treatment on the papaya fruit epidermis. Food and Bioproducts Processing, London, v.90, n.2, p.118-122, 2012.

KEUTGEN, A.J.; PAWELZIK, E. Influence of preharvest ozone exposure on quality of strawberry fruit under simulated retail conditions. Postharvest Biology and Ttechnology, Amsterdam, v.49, n.1, p.10-18, 2008.

KIM, J. G. e YOUSEF, A. E. Inactivation kinetics of foodborne spoilage and pathogenic bacteria by ozone. Journal of Food Science, v. 65, n. 3, p. 521-528, 2000.

KIM, J.G.; YOUSEF, A.E.; KHADRE, M.A. Ozone and its current and future application in the food industry. Advances in Food and Nutrition Research, San Diego, v.45, p.167-218, 2003.

KLOCKOW, P.A e KEENER, K.M. Safety and quality assessment of packaged spinach treated with a novel ozone-generation system. LWT-Food Science and Technology, Amsterdam, v.42, n.6, p.1047-1053, 2009.

LIBERATO, J.R.; TATAGIBA, J.S. Avaliação de fungicidas in vitro e em pós-colheita para o controle da antracnose e da podridão peduncular em frutos de mamão. Summa Phytopathologica, Botucatu, v.26, n.4, p.409-14, 2001.

MAHFOUDH, A.; MOISAN, M.; SEGUIN, J.; BARBEAU, J.; KABOUZI, Y.; KEROACK, D. Inactivation of vegetative and sporulated bacteria by dry gaseous ozone. Ozone: Science \& Engineering, Chelsea, v.32, n.3, p.180-198, 2010.

MILLER, F.A.; SILVA, C.L.; BRANDÃO, T.R. A review on ozone-based treatments for fruit and vegetables preservation. Food Engineering Reviews, New York, v.5, n.2, p.77-106, 2013.
MINAS, I.S.; TANOU, G.; BELGHAZI, M.; JOB, D.; MANGANARIS, G.A.; MOLASSIOTIS, A.; VASILAKAKIS, M. Physiological and proteomic approaches to address the active role of ozone in kiwifruit post-harvest ripening. Journal of Experimental Botany, Amsterdam, v.63, p.2449-2464, 2012.

MODESTI, M.; PETRICCIONE, M.; FORNITI, R.; ZAMPELLA, L.; SCORTICHINI, M.; MENCARELLI, F. Methyl jasmonate and ozone affect the antioxidant system and the quality of wine grape during postharvest partial dehydration. Food Research International, New York, v.112, p.369-377, 2018.

ONG, M.K.; KAZI, F.K.; FORNEY, C.F.; ALI, A. Effect of gaseous ozone on papaya anthracnose. Food and Bioprocess Technology, New York, v.6, n.11, p.29963005, 2013.

ONG, M.K.; ALI, A. Antifungal action of ozone against Colletotrichum gloeosporioides and control of papaya anthracnose. Postharvest Biology and Technology, Amsterdam, v.100, p.113-119, 2015.

OZKAN, R.; SMILANICK, J.L.; KARABULUT, O.A. Toxicity of ozone gas to conidia of Penicillium digitatum, Penicillium italicum and Botyris cinerea and control of gray mold on table grapes. Postharvest Biology and Technology, Amsterdam, v.60, n.1, p.47-51, 2011.

PALOU, L.; CRISOSTO, C.H.; SMILANICK, J.L.; ADASKAVEG, J.E.; ZOFFOLI, J.P. Effects of continuous $0.3 \mathrm{ppm}$ ozone exposure on decay development and physiological responses of peaches and table grapes in cold storage. Postharvest Biology and Technology, Amsterdam, v.24, n.1, p.39-48, 2002.

PATIL, S.; BOURKE, P.; FRIAS, J.M.; TIWARI, B.K.; CULLEN, P.J. Inactivation of Escherichia coli in orange juice using ozone. Innovative Food Science \& Emerging Technologies, New York, v.10, n.4, p.551$557,2009$.

PIMENTEL, J.D.R.; SOUZA, D.S.; DE OLIVEIRA, T.V.; DA COSTA OLIVEIRA, M.; BASTOS, V.; CASTRO, A.A. Estudo da conservação de mamão Havaí utilizando películas comestíveis a diferentes temperaturas. Scientia Plena, Aracaju, v.7, n.10, p.1-6, 2011. 
QIANG, Z.; DEMIRKOL, O.; ERCAL, N.; ADAMS, C. Impact of food disinfection on beneficial biothiol contents in vegetables. Journal of Agricultural and Food Chemistry, Washington, v.53, n.25, p.9830-9840, 2005.

REIS, R.C.; VIANA, E.D.S.; JESUS, J.L.D.; DANTAS, J.L.L.; LUCENA, R.S. Physicochemical characterization of new hybrids and inbred lines of papaya. Pesquisa Agropecuária Brasileira, Brasília, DF, v.50, n.3, p.210217, 2015a.

REIS, R.C.; VIANA, E.D.S.; DE JESUS, J.L.; LIMA, L.F.; NEVES, T.T.D.; CONCEIÇÃO, E.A.D. Bioactive compounds and antioxidant activity of improved varieties of papaya. Ciência Rural, Santa Maria, v.45, n.11, p.2076-2081, 2015b.

RIBEIRO, J.G.; SERRA, I.M.R.D.S.; ARAÚJO, M.U.P. Use of natural products to control anthracnose caused by Colletotrichum gloeosporioides in papaya. Summa Phytopathologica, Botucatu, v.42, n.2, p.160-164, 2016.

RODONI, L.; CASADEI, N.; CONCELLÓN, A.; CHAVES ALICIA, A. R.; VICENTE, A. R. Effect of short-term ozone treatments on tomato (Solanum lycopersicum L.) fruit quality and cell wall degradation. Journal of Agricultural and Food Chemistry, Washington, v.58, n.1, p.594-599, 2009.

SHARPE, D.; FAN, L.; MCRAE, K.; WALKER, B.; MACKAY, R.; DOUCETTE, C.. Effects of ozone treatment on Botrytis cinerea and Sclerotiniasclerotiorum in relation to horticultural product quality. Journal of Food Science, Chiago, v.74, n.6, p.250 - 257, 2009.

SKOG, C.L.; CHU, L.J. Effect of ozone on qualities of fruits and vegetables in cold storage. Canadian Journal of Plant Science, Ottawa, v.81, n.4, p.773-778, 2001.

SOUSA, A.E.D.; FONSECA, K.S.; DA SILVA GOMES, W.K.; DA SILVA, A.P.M.; DE OLIVEIRA SILVA, E.; PUSCHMANN, R. Control of browning of minimally processed mangoes subjected to ultraviolet radiation pulses. Journal of Food Science and Technology, New Delhi, v.54, n.1, p.253-259, 2017.

SOUSA, A.E.D.; LOPES, M.M.A.; MOREIRA, A.D.R.; MACEDO, J.N.; MOURA, C.F.H.; DE ARAGÃO, F.A.S.; ZOCOLO, G.J.; DE MIRANDA, M.R.A.; SILVA, E.O. Induction of postharvest resistance in melon using pulsed light as abiotic stressor. Scientia Horticulturae, New York, v.246, p.921-927, 2019.
SOUZA,A.F.; SILVA, W.D.; GONÇALVES, Y.S.; SILVA, M.D.; OLIVEIRA, J.D. Fisiologia do amadurecimento de mamões de variedades comercializadas no Brasil. Revista Brasileira de Fruticultura, Jaboticabal, v.36, n.2, p.318-328, 2014.

SUÁREZ-QUIROZ, M.L.Q.; MENDOZA-BAUTISTA, I.; MONROY-RIVERA, J.A.; CRUZ-MEDINA, J.; ANGULO-GUERRERO, O.; GONZÁLEZ-RÍOS, O. Aislamiento, identificación y sensibilidad a antifúngicos de hongos fitopatógenos de papaya cv.Maradol (Carica papaya L.) Revista Iberoamericana de Tecnología Postcosecha, Hermosillo, v.14, n.2, p.115-124, 2013.

THANOMSUB, B.; ANUPUNPISIT, V.; CHANPHETCH, S.; WATCHARACHAIPONG, T.; POONKHUM, R.; SRISUKONTH, C. Effects of ozone treatment on cell growth and ultrastructural changes in bacteria. The Journal of General and Applied Microbiology, Tokyo, v.48,193-199, 2002.

TRINETTA, V.; VAIDYA, N.; LINTON, R.; MORGAN, $M$. A comparative study on the effectiveness of chlorine dioxide gas, ozone gas and e-beam irradiation treatments for inactivation of pathogens inoculated onto tomato, cantaloupe and lettuce seeds. International Journal of Food Microbiology, Amsterdam, v.146, n.2, p.203206, 2011.

TZORTZAKIS, N.G.; SINGLETON, I.; BARNES, J.D. Deployment of low level ozone-enrichment for the preservation of chilled fresh produce. Postharvest Biology and Technology, Amsterdam, v.43, n.2, p.261270, 2007.

VENTA, M.B.; BROCHE, S.S.C.; TORRES, I.F.; PÉREZ, M.G.; LORENZO, E.V.; RODRIGUEZ, Y.R.; CEPERO, S.M. Ozone application for postharvest disinfection of tomatoes. Ozone: Science \& Engineering, Chelsea, v.32, n.5, p.361-371, 2010.

VIANA, E.S.; REIS, R.C.; DA SILVA, S.C.S.; DAS NEVES, T.T.; DE JESUS, J.L. Avaliação físico-química e sensorial de frutos de genótipos melhorados de mamoeiro. Pesquisa Agropecuária Tropical, Brasília, DF, v.45, n.3, 2015.

YEOH, W.K.; ALI, A.; FORNEY, C.F. Effects of ozone on major antioxidants and microbial populations of fresh-cut papaya. Postharvest Biology and Technology, Amsterdam, v.89, p.56-58, 2014.

ZAMBRE, S. S.; VENKATESH, K. V.; SHAH, N.G. Tomato redness for assessing ozone treatment to extend the shelf life. Journal of Food Engineering, Amsterdam, v.96, n.3, p.463-468, 2010. 
Revista Brasileira de Fruticultura, 43(5): e-439erratum

https://dx.doi.org/10.1590/0100-29452019439erratum

\section{Erratum of article:}

Silva, Osvaldo Pereira da et al. Ozone slows down anthracnose and increases shelf life of papaya fruits. Revista Brasileira de Fruticultura. 2019, v. 41, n. 5, e-439. Available from: https://doi.org/10.1590/0100-29452019439

In the page 1, add the note:

\section{Financial disclousure}

This work was developed and published with the support of the Government of the State of Amazonas through the Amazonas State Research Support Foundation - PAPAC/FAPEAM) 